To cite: M Mhango 'The right to equality and access to courts for government employees in South Africa: Time to amend the Government Employees Pension Law' (2019) 19 African Human Rights Law Journal 337-360

http://dx.doi.org/10.17159/1996-2096/2019/v19n1a16

\title{
The right to equality and access to courts for government employees in South Africa: Time to amend the Government Employees Pension Law
}

\author{
Mtendeweka Mhango* \\ Professor of Law, National University of Lesotho, Roma \\ https://orcid.org/0000-0001-7976-4473
}

\begin{abstract}
Summary
This article comments on the South African Government Employees Pension Law by highlighting a constitutional defect arising out of the parallel pension regime in the country which has yet to be resolved. Since the 1996 amendments to the Pension Funds Act Law, members of pension funds governed by that Act have enjoyed the advantage of access to a specialised pension tribunal known as the Office of the Pension Funds Adjudicator, whose functions are performed by the Pension Funds Adjudicator. The problem is that members of government funds do not have access to the Office of the Pension Funds Adjudicator nor does any legislation specific to government funds make provision for a similar advantage and benefit. While this article focuses its analysis on the impugned provisions of the Government Employees Pension Law, the arguments advanced against those provisions apply with equal force to legislation establishing other government funds. The article argues that the Government Employees Pension Law is unconstitutional to the extent that it does not afford members of the Government Employees Pension Fund the advantage of and access to the dispute resolution services at the Office of the Pension Funds Adjudicator or a similar tribunal. Although this article concerns itself with the position in South Africa, the constitutional argument is relevant to other countries (in Africa and elsewhere) that have comparable legal regimes in place.
\end{abstract}

Key words: pension fund; equality; fair trial; dispute resolution; employees; pension benefits 


\section{Introduction}

In the early 1990s South Africa underwent radical democratic and constitutional reforms. These reforms had a direct impact on the $\$ 207$ billion private pension funds industry. Among the specific areas affected by these reforms are (a) the manner in which pension funds are governed by requiring equal representation between employees and employers on the boards of management; ${ }^{2}$ (b) the manner in which pension disputes are resolved through the establishment of a specialised pension tribunal; ${ }^{3}$ and (c) the manner in which pension benefits are designed and administered by subjecting pension funds to the Bill of Rights. ${ }^{4}$ However, for the purpose of this discussion the most important impact of those reforms was the policy decision taken by the government to maintain a parallel legal regime for private pension funds. As a result of this decision, the general rule is that all private pension funds in South Africa are governed by the Pension Funds Act 24 of 1956. The exception to that rule is those private pension funds (referred to as government funds) that are governed by specific statutes unique to those government funds. This set of government funds include the Government Employees Pension Fund

1 Willis Towers Watson 'Global pension assets study 2017' https://www. willistowerswatson.com/en/insights/2017/01/global-pensions-asset-study-2017 (accessed 3 May 2017).

2 For further discussion on the governance of pension funds in South Africa, see J Murphy 'Alternative dispute resolution in the South African pension funds industry: An ombudsman or tribunal?' (2001) 7 Journal of Pensions Management 27 29. See also M Mhango 'Adjudicating insurance and pension products under the South African Pension Funds Act 24 of 1956' (2014) 28 Speculum Juris 102-105; and C Marumoagae 'Do boards of trustees of South African retirement funds owe fiduciary duties to both the funds and fund members? The debate continues' (2012) 15 Potchefstroom Electronic Law Journal 554.

3 For further discussion, see $\mathrm{N}$ Jeram 'The Pension Funds Adjudicator: A jurisdictional nightmare' (2005) 38 Industrial Law Journal 1825; M Mhango 'Does the South African Pension Funds Adjudicator perform an administrative or judicial function?' (2016) 20 Law, Democracy and Development 24.

4 See Sebola $v$ Johnson Tiles (Pty) Ltd \& Others [2002] 3 BPLR 3242 (PFA) (rule formulated for an illegitimate purpose and therefore ultra vires and unconstitutional); Jooste v MPF Management Services (Pty) Ltd \& Others [2000] 11 BPLR 1234 (PFA) (suggesting that the Adjudicator is empowered to strike down or rewrite pension fund rules where illegality or unconstitutionality is found); Kransdorff $v$ Sentrachem Pension Fund \& Another [1999] 9 BPLR 55 (PFA) (found that unreasonable withdrawal benefit rules violated the constitutional right to property); Olivier v Mine Employees Pension Fund [2002] 11 BPLR 4068 (PFA); Wilson v Orion Fixed Benefit Pension Fund \& Others (1) [1999] 9 BPLR 89 (PFA); Martin v Beka Provident Fund [2000] 2 BPLR 196 (PFA) (the complainant who had been involved in a domestic same-sex relationship with the deceased sought payment of the spouse's pension and death benefits in terms of the rules of the fund. The rule discriminated between heterosexual partners and same-sex partners in its definition of spouse. The Adjudicator found that the discrimination on the grounds of sexual orientation was offensive and rendered the definition unconstitutional. He ordered the trustees to amend the rule accordingly.) 
(GEPF); ${ }^{5}$ the Post Office Retirement Fund; ${ }^{6}$ and the Transnet Pension. ${ }^{7}$

One of the benefits of the current parallel pension regime is that it allows the government of the day greater control in the affairs of government funds on matters that affect the national budget. This is relevant given that most government funds, particularly the GEPF, are organised as defined benefit funds where issues of the adequacy of funding levels may have significant political and economic consequences. ${ }^{8}$ In other words, at the core of the concern and the need for greater control is the fact that an employer who participates in a defined benefit fund, such as the government of South Africa in this context, guarantees the pension benefits regardless of the investment performance of government funds. ${ }^{9}$ In the South African setting, this guarantee, especially in relation to the GEPF, is quite significant and justifies the parallel private pension regime to ensure greater control of government funds.

Sustaining a parallel pension regime has had the negative effect of significant omissions by the political branches of the state of South Africa to keep up with the reforms in the Pension Funds Act and other modernisation efforts applied to the increasingly dynamic private pension system. This omission has led to constitutional problems, some of which have in recent years been resolved by the judiciary. ${ }^{10}$

5 Established in terms of the Government Employees Pension Law, Proclamation 21 of 1996.

6 Established in terms of the Post Office Act 44 of 1958.

7 Established in terms of the Transnet Pension Fund Act 62 of 1990.

8 For a discussion of some of the funding and other challenges in public pension funds, see D Hess 'Protecting and politicising public pension fund assets: Empirical evidence on the effects of governance structures and practices' (2005) 39 UC Davis Law Review 187; F Hess \& I Squire 'But the pension fund was just sitting there ...': The politics of teacher retirement plans' (2010) 5 Education Finance and Policy 587; T Fitzpatrick \& A Monahan 'Who's afraid of good governance? State fiscal crises, public pension underfunding, and the resistance to governance reform' (2015) 66 Florida Law Review 1317.

9 See sec 31 of the Government Employees Pension Law which provides that '[t]his Law shall bind the state and the government shall be responsible for meeting the obligations of the Fund, whether properly funded or not, in favour of its members, pensioners and beneficiaries: Provided that any change in the investment policy of the Fund referred to in section 6(7) or the benefit structure of the Fund, as provided for in the rules which may have an effect on the government's financial obligation towards the Fund, shall be subject to the approval of the Minister: Provided further that the Minister's approval shall not be required in the event of changes to the benefit structures brought about by agreements reached in the bargaining structures for the public service.'

10 See Pretorius \& Another v Transnet Second Defined Benefit Fund \& Others [2014] ZAGPPHC 526; 2014 (6) SA 77 (GP). See also L Shrosbree 'To what extent does section 37D of the Pension Funds Act protect employers from dishonest conduct by their employees' (2005) 37 Industrial Law Journal 17 (arguing that sec 37D of the Pension Funds Act provides greater protection to members of pension funds than sec 21(3)(c) of the Government Employees Pension Law by requiring the procurement of a civil judgment against the member as the legal basis for the possible deduction of pension benefits by a pension fund. The author notes that unlike the Pension Funds Act, the Government Employees Pension Law does not make a civil judgment necessary. Instead, it simply requires that the amount of 
For instance, in Wiese $v$ Government Employees Pension Fund, ${ }^{11}$ the High Court found the Government Employees Pension Law unconstitutional as it failed to provide equal protection and benefit of the law, as guaranteed by section 9(1) of the Constitution, afforded to non-member spouses of members of pension funds subject to the Pension Funds Act. In other words, unlike divorced spouses of members of pension funds regulated by the Pension Funds Act, who enjoyed the benefit of the 'clean break principle' which gave them immediate access to their share of the pension interest at the date of divorce, divorced spouses of members of the GEPF and other government funds did not enjoy the same benefit upon divorce. Two years after Wiese was decided and the government complied by amending the Government Employees Pension Law, a similar cause of action was lodged in Ngewu $v$ Post Office Retirement Fund. ${ }^{12}$ As was the case in Wiese, the Constitutional Court found that the omission of the clean break principle from the provisions of the Post Office Act rendered that Act invalid.

The article comments on the Government Employees Pension Law by highlighting another constitutional defect arising out of the parallel pension regime in South Africa, which has yet to be resolved. Since the 1996 amendments to the Pension Funds Act, members of pension funds governed by that Act have enjoyed the advantage of access to a specialised pension tribunal known as the Office of the Pension Funds Adjudicator (OPFA), whose functions are performed by the Pension Funds Adjudicator (Adjudicator). ${ }^{13}$ The problem here is that members of government funds do not have access to the OPFA, nor does any legislation specific to government funds make provision for a similar advantage and benefit. While the article focuses its analysis on the impugned provisions of the Government Employees Pension Law, the arguments advanced against those provisions apply with equal force to legislation establishing other government funds.

The parallel pension regulatory regime is not unique to South Africa. The Kingdom of Lesotho has a similar set-up whereby public employees are compelled to become members of the Public Officers Defined Contribution Pension Fund which is regulated by its own specific legislation known as the Public Officers Defined Contribution Pension Fund Act 2008, ${ }^{14}$ while other private pension funds are regulated by the Income Tax (Superannuation and LIfe Assurance)

loss to the employer on the basis of which a deduction is sought must have been proved in court.)

11 Wiese v Government Employees Pension Fund (2011) 4 All SA 280 (WCC) (Wiese 1). See also Wiese v Government Employees Pension Fund \& Others 2012 (6) BCLR 599 (CC).

122013 (4) BCLR 421 (CC).

13 See sec 30B of the Pension Funds Act.

14 For a discussion, see M Mhango \& NV Dyani-Mhango 'Reform of the death benefit provisions in Lesotho's public sector pension fund: Lessons from South Africa and Swaziland' (2016) 24 African Journal of International and Comparative Law 199; M Mhango 'Constitutional challenges in the implementation of a 
Regulations 1994 and the soon to be promulgated Pension Bill of 2018. In addition, while most African countries have adopted specific statutory social security schemes to cover public employees in ways that are distinct from the South African situation, the constitutional arguments and analysis advanced in this article, involving the right to equality and access to courts as well as the imperative for special dispute resolution procedures similar to that of the OPFA, are relevant to many other African countries.

The article argues that the Government Employees Pension Law is unconstitutional to the extent that it does not afford members of the GEPF the advantage of and access to the dispute resolution services at the OPFA or similar tribunal. The article is divided in four parts. Part 1 discusses a few relevant provisions of the Government Employees Pension Law. Part 2 examines the dispute resolution system in the Pension Funds Act to demonstrate some of the advantages enjoyed by members of pension funds governed by that Act. Part 3 examines the current constitutional equality framework and jurisprudence to demonstrate the invalidity of the Government Employees Pension Law. Given that the constitutional defects highlighted in the article cannot be substantively cured through judicial review because of separation of powers imperatives, the last part of the article draws attention to a range of constitutional and policy considerations that the executive and legislature need to take into account in order to cure the constitutional defects.

\section{Relevant parts of the Government Employees Pension Law}

The GEPF is a defined benefit pension fund, which means that it guarantees benefits to all of its 1,2 million active members and 400000 and more pensioners. ${ }^{15}$ It is the largest pension fund in Africa, and is ranked among the top 20 largest pension funds in the world in terms of assets under its control and administration. The GEPF was established by section 3 of the Government Service Pension Act 57 of 1973, and was renamed and continues to exist as a juristic person by virtue of section 2 of the Government Employees Pension Law. The objectives of the GEPF are encapsulated in section 3 of the Government Employees Pension Law, which provides that '[t]he object of the Fund shall be to provide the pensions and certain other related benefits as determined in this Law to members and pensioners and their beneficiaries'.

Section 6 of the Government Employees Pension Law vests the management and governance of the GEPF in a board of trustees,

compulsory pension fund: The case of Lesotho (2014) 131 South African Law Journal 408.

15 See www.gepf.gov.za (accessed 25 March 2019). 
which is comprised of both the employer and employees. This section provides, in pertinent parts, as follows:

(1) There is hereby established a board which shall be known as the Board of Trustees and which shall be constituted as prescribed.

(2) The Board shall manage the Fund and shall in respect thereof exercise the powers, perform the functions and carry out the duties conferred upon, assigned to or imposed upon it in terms of this Law.

(3) Members and pensioners of the Fund shall be entitled to representation on the Board, which representation shall collectively be equal in number to the representation by the employer as prescribed.

(4) The first meeting of the Board shall take place at a time and place to be determined by the Minister, and any subsequent meeting of the Board shall take place at a time and place determined in terms of the rules.

(5) The procedure to be followed at a meeting of the Board, the quorum for such a meeting, and the majority of votes required for a decision of the Board, shall be as prescribed.

(6) The Board may delegate any of its powers, functions or duties to a management committee, committee or person to be exercised, performed or carried out, subject to such conditions as may be determined by the Board.

(7) The Board, acting in consultation with the Minister, shall determine the investment policy of the Fund.

In addition to conferring the power to manage the GEPF on the board of trustees, the Government Employees Pension Law confers additional powers on the board of trustees to make rules or regulations for the GEPF. In this regard, section 29 of the Government Employees Pension Law is instructive. It provides:

(1)(a)Subject to the provisions relating to negotiations regarding the terms and conditions of employment contained in any law applying in respect of labour relations arrangements in the public service, including education, and subject to negotiations in accordance with any labour relations legislation or arrangements applicable to the South African Police Service, the South African National Defence Force, the National Intelligence Agency and the South African Secret Service regarding their terms and conditions of employment, the Board shall make rules with regard to -

(i) the constitution of the Board and the management and administration of the Fund;

(ii) the payment of contributions to the Fund and the payment of benefits from the Fund to or in respect of members on their retirement, discharge, resignation or death;

(iii) any matter in respect of dormant members of the Fund;

(iv) any matter required or permitted to be prescribed under this Law, and, generally, for the better achievement of the objects and purposes of this Law.

(5) The Rules shall be binding on the government, the Fund, its members and pensioners and their beneficiaries or any other person who has a claim against the Fund.

Unlike the Pension Funds Act, the Government Employees Pension Law does not establish a tribunal such as the OPFA nor does it 
establish any other mechanism or procedures to resolve disputes arising from its implementation. The only reference to a dispute resolution system is contained in Rule 10 of the GEPF, which governs the recognition of pensionable service. Rule 10 reads, in pertinent parts, as follows:

10 Recognition of previous and other periods of services as pensionable service

Subject to the provisions of the rules any part or the whole of any of the undermentioned periods may at the written request of a member and with the approval of the Board be recognised as pensionable service -

10.6 a period of NSF Service, ${ }^{16}$ provided that a period of NSF Service may only be recognised on the following conditions:

(a) the former member of a non-statutory force or service, or beneficiary of a former member on a non-statutory force or service where the former member of a non-statutory force or service is deceased, completes an application form as formulated by the Fund, and returns the completed form to the Fund within a period of eighteen months after the date of commencement of this rule, provided that the Board may, on good cause shown, consider an application submitted after the eighteen months period referred to in this paragraph: Provided further that when the application form, submitted by a beneficiary of a former member of a non-statutory force or service, is considered by the Board the Board may in the case of a dispute between beneficiaries regarding the application decide in its sole discretion whether to and to what extent to recognise the NSF Service applied for ...

In terms of the above provision the board of trustees of the GEPF has a complete discretion to resolve, in the first instance, any pension dispute between beneficiaries concerning recognition of pensionable service. Presumably, in the event that beneficiaries are not satisfied with the contemplated resolution by the board of trustees they may approach a court. However, what is clear is that the OPFA is not an option for such disgruntled beneficiaries. The legal position is different for similar members or beneficiaries under the Pension Funds Act. This position is outlined below.

16 This term is defined in the rules of the GEPF as 'the period between the date on which a former member of a non-statutory force or service joined his or her respective former forces or services (as reflected on his or her service certificate) and the date of their taking up employment, or entering into an agreement with or their attestation into the employer, provided that such service will only be recognised for the period after the former member of a non-statutory force or service attained the age of sixteen years, so that service prior to the age of sixteen years will not be regarded as NSF Service. In the case of a beneficiary of a former member of a non-statutory force or service, NSF Service means the period of NSF Service of the former member of a non-statutory force or service through whom the beneficiary is entitled to a benefit in terms of the Fund'. 


\section{Dispute resolution framework under the Pension Funds Act}

As alluded to earlier, the constitutional reforms of the 1990s directly impacted on the pension funds industry. In one of the earliest studies of this impact, particularly in relation to private pension dispute resolution in South Africa, Murphy correctly observed: ${ }^{17}$

Pursuant to recommendations made by the Mouton Committee of Investigation into a Retirement Provision System for South Africa, the Pension Funds Act in South Africa was amended to create a special process by which complaints against pension funds can be investigated and decided.

It is important to point out that the Mouton Committee recommended the establishment of the OPFA as the Pension Funds Act did not make provision for an independent body to resolve disputes between members of private pension funds and their pension funds. ${ }^{18}$ Yet, the Registrar of Pension Funds was flooded with complaints by pension fund members and beneficiaries despite the Registrar not being conferred with the authority to dispose of pension disputes. $^{19}$

Political parties represented in Parliament in 1996 supported the creation of the OPFA. In his speech supportive of the OPFA, Dr Botha of the Freedom Front Plus Party made the following remarks, which capture the problem and solution at the time: 20

The appointment of the [Adjudicator] is the second matter I want to single out, which we support very strongly. At the moment ... no provision exists for the hearing and adjudication of complaints in the pension funds industry. The registrar of pension funds also has insufficient powers to deal with complaints effectively. Members do have access to courts, but we all know that this is very expensive, lengthy and complex. The Mouton Committee to which the Deputy Minister referred, recommended the appointment of an ombudsman with only conciliatory powers, but that is not good enough either. It has been recommended that an Adjudicator should be appointed for pension funds [and with sufficient powers]. This

17 See 'The Report of the Committee of Investigation into a Retirement Provision System for South Africa' 323 (1992) (Mouton Committee Report); Murphy (n 2) 28; Jeram (n 3) 1827. See also Mhango (n 2) 103 (discussing pension reforms in the 1990s); M Sigwadi 'Dispute resolution and the Pension Funds Adjudicator' (2004) 12 Juta's Business Law Journal 2; N Jeram 'Jurisdiction of the Pension Funds Adjudicator in respect of complaints by underwritten insurers' (2010) Insurance and Tax Journal; L Nevondwe \& K Odeku 'An analysis of the role of the Pension Funds Adjudicator in South Africa' (2013) 4 Mediterranean Journal of Social Sciences 829.

18 See Mouton Committee Report (n 17) 324.

19 See Mouton Committee Report (n 17) 323. The Registrar is a creature of statute established under sec 3 of the Pension Funds Act read with sec 1 of the Financial Services Board Act 97 of 1990 to supervise and regulate private pension funds that are subject to the Pension Funds Act. However, see the Financial Sector Regulation Act 9 of 2017 which repealed the Financial Services Board Act and created the Financial Sector Conduct Authority to replace the Registrar. 
Adjudicator can contribute positively to the protection of members. The details are set out in the Bill. The Adjudicator will also serve as an economic and effective mechanism to deal with complaints.

In the end, through an amendment to the Pension Funds Act, which came into effect in April 1996, the OPFA was established. In terms of section $30 \mathrm{~B}(2)$ of the Pension Funds Act, the work of the OPFA is performed by the Adjudicator, whose function is to dispose of complaints relating to private pension funds in a 'procedurally fair, economical and expeditious manner'. ${ }^{21}$ A complaint, which is the primary source of the Adjudicator's jurisdiction, is defined in section 1 of the Pension Funds Act as follows: ${ }^{22}$

Complaint means a complaint of the complainant relating to the administration of a fund, the investment of its funds or the interpretation and application of its rules and alleging -

(a) that a decision of the fund or any person purportedly taken in terms of the rules was in excess of the powers of that fund or person, or an improper exercise of its powers;

(b) that the complainant has sustained or may sustain prejudice in consequence of the maladministration of the fund by the fund or any person whether by act or omission;

(c) that a dispute of fact or law has arisen in relation to the fund between the fund or any person and the complainant.

In order to promote access to justice the courts have ruled that the dispute resolution provisions in the Pension Funds Act should be broadly construed to incorporate lay complainants, who may not be able to formulate their complaints with legal precision. ${ }^{23}$ In other words, a mere letter, including a handwritten letter, by a lay complainant which contains sufficient allegations should be deemed to fall within the definition of a complaint. ${ }^{24}$ In justifying a broad construction of the jurisdiction of the Adjudicator in favour of

21 Sec 30D of the Pension Funds Act. See also Mhango (n 2) 104.

22 See Pienaar $v$ Consol Group Pension Fund PFA/GA/97/98 (unreported), where an employer failed to file a disability claim with the Fund on behalf of the complainant. In a dispute seeking to order the employer to provide evidence to the Fund for the consideration of the disability claim, the Adjudicator held that the dispute was not a complaint as defined in the Pension Funds Act; Seethal $v$ Metal and Engineering Industries Permanent Disability Scheme PFA/KZN/2719/01 (unreported) where it was held that a permanent disability scheme does not fall within the definition of a pension fund organisation; Stassen $v$ Central Retirement Annuity Fund 2001 (3) BPLR 1792 where the Adjudicator held that he did not have jurisdiction to hear a dispute relating to a divorce order where the court order was not served on the Fund; and Alais v Telkom Pension Fund 2006 (1) BPLR 67 (PFA) where it was held that the Adjudicator has no jurisdiction to determine whether or not a reorganisation of an employer has taken place even where pension matters are involved.

23 Central Retirement Annuity Fund v Adjudicator of Pension Fund (2006) 4 All SA 251; Mungal v Old Mutual Life Assurance Co SA Ltd 2010 (6) SA 98 (SCA); M Mhango and N Dyani-Mhango 'Reflections on transformative pension adjudication' (2017) 38 Industrial Law Journal 2173. 
untrained complainants, the Supreme Court of Appeal in Mungal reasoned as follows: ${ }^{25}$

The complaints in this case were conveyed to the adjudicator in letters written by Mungal and Freeman. Needless to say they were not framed in the language of the definition but I do not think the form in which a complaint is made is critical. Chapter VA clearly contemplates complaints being made by lay persons who are not expected to have studied the definition with legal expertise and to have framed their complaints accordingly. More important than the form in which the complaint is expressed is the substance of the complaint. If the various elements of the definition are inherent in the complaint that seems to me to sufficiently bring it within the terms of the definition notwithstanding that they have not been expressed in those terms.

After investigating a complaint as defined, the Adjudicator is empowered to 'make the order which any court of law may make', 26 which 'shall be deemed to be a civil judgment of any court of law had the matter in question been heard by such court'. ${ }^{27}$ Further, any person who is aggrieved by a determination of the Adjudicator may apply to an appropriate High Court for relief in terms of section 30P of the Pension Funds Act, in which case the High Court 'may consider the merits of the complaint ... and may make any order it deems $\mathrm{fit}^{\prime}{ }^{28}$ In its interpretation of the scope of section 30P, the Supreme Court of Appeal in Meyer $v$ Iscor Pension Fund ${ }^{29}$ declared: 30

From the wording of $s 30 P(2)$ it is clear that the appeal to the High Court contemplated is an appeal in the wide sense. The High Court is therefore not limited to a decision whether the Adjudicator's determination was right or wrong. Neither is it confined to the evidence or the grounds upon which the Adjudicator's determination was based. The Court can consider the matter afresh and make any order it deems fit. At the same time, however, the High Court's jurisdiction is limited by s 30P(2) to a consideration of 'the merits of the complaint in question'. The dispute submitted to the High Court for adjudication must therefore still be a 'complaint' as defined.

Against this background, the OPFA became operational in $1998 .^{31}$ Since then, it has played a significant role in the development of pension jurisprudence. ${ }^{32}$ Nonetheless, policy questions remain unresolved around the jurisdictional reach of the Adjudicator, including the question whether the Adjudicator performs

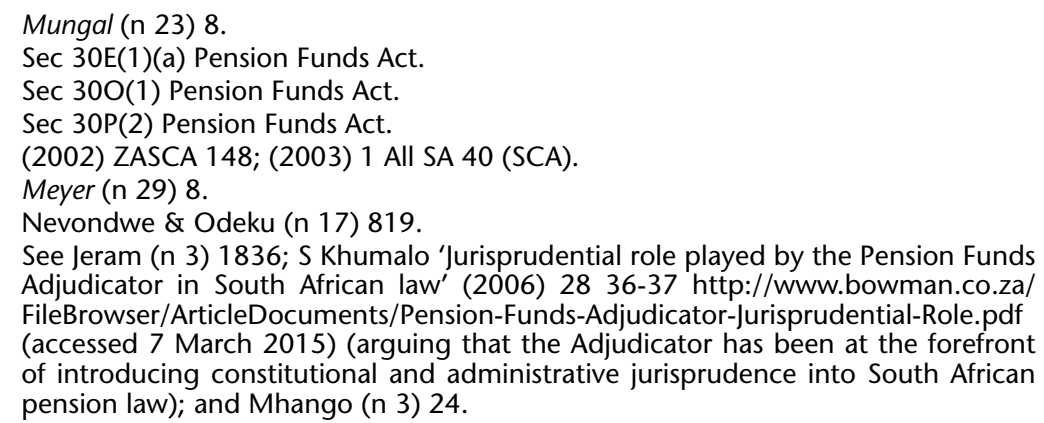
FileBrowser/ArticleDocuments/Pension-Funds-Adjudicator-Jurisprudential-Role.pdf (accessed 7 March 2015) (arguing that the Adjudicator has been at the forefront of introducing constitutional and administrative jurisprudence into South African pension law); and Mhango (n 3) 24. 
administrative or judicial powers or whether it has advanced transformative adjudication over the years. ${ }^{33}$ Whatever the answers to these policy questions might be, the Adjudicator continues to operate and provide the benefit of judicial services to members of the public whose pension funds are regulated under the Pension Funds Act.

\section{Constitutional framework on equality}

\subsection{Harksen inquiry}

The problem highlighted in this article involves a conflict between the provisions of the Government Employees Pension Law and the rights to human dignity in section 10 of the South African Constitution; access to social security in section 27 of the Constitution; access to courts in section 34 of the Constitution; and the right to equality in section 9 of the Constitution. Section 9, which at this stage is the focus of the article, provides:

(1) Everyone is equal before the law and has the right to equal protection and benefit of the law.

(2) Equality includes the full and equal enjoyment of all rights and freedoms. To promote the achievement of equality, legislative and other measures designed to protect or advance persons, or categories of persons, disadvantaged by unfair discrimination may be taken.

(3) The state may not unfairly discriminate directly or indirectly against anyone on one or more grounds, including race, gender, sex, pregnancy, marital status, ethnic or social origin, colour, sexual orientation, age, disability, religion, conscience, belief, culture, language and birth.

(4) No person may unfairly discriminate directly or indirectly against anyone on one or more grounds in terms of subsection (3). National legislation must be enacted to prevent or prohibit unfair discrimination.

(5) Discrimination on one or more of the grounds listed in subsection (3) is unfair unless it is established that the discrimination is fair.

The courts have held that the above provision protects both formal and substantive equality. ${ }^{34}$ Formal equality is contemplated in subsection (1), whereas subsection (2) contemplates substantive

33 See Mhango \& Dyani-Mhango (n 23); Jeram (n 3) 1825 (arguing that due to the badly-drafted mandate of the Adjudicator, the resolution of pension disputes is a jurisdictional nightmare and pension fund members are consistently confronted with a series of points in limine); Khumalo (n 32) 39 (generally agreeing that there are many problems surrounding the jurisdiction of the Adjudicator); Mhango (n 3) 20-45.

34 See Minister of Finance \& Others $v$ Van Heerden 2004 (6) SA 121 (CC); National Coalition for Gay and Lesbian Equality v Minister of Justice 1999 (1) SA 6; 1998 (12) BCLR 1517 (CC); South African Police Service v Barnard 2014 (6) SA 123 (CC) para 28 (where it was held that 'the foremost provision in our equality guarantee is that everyone is equal before the law and is entitled to equal protection and benefit of the law. But, unlike other constitutions, ours was designed to do more 
equality. It is in this context that the Court has emphasised that the society envisioned by the Constitution is one based on the values of human dignity, the achievement of equality and the advancement of human rights and freedoms. ${ }^{35}$ It has consistently held that the achievement of equality (formal or substantive) is one of the fundamental objectives of the Constitution. ${ }^{36}$ In one of the earliest cases dealing with the right to equality, the Court explained the following difficulties faced by any modern government: ${ }^{37}$

It must be accepted that, in order to govern a modern country efficiently and to harmonise the interests of all its people for the common good, it is essential to regulate the affairs of its inhabitants extensively. It is impossible to do so without differentiation and without classifications which treat people differently and which impact on people differently ... Differentiation which falls into this category very rarely constitutes unfair discrimination in respect of persons subject to such regulation, without the addition of a further element. It is convenient, for descriptive purposes, to refer to the differentiation presently under discussion as 'mere differentiation'. In regard to mere differentiation the constitutional state is expected to act in a rational manner. It should not regulate in an arbitrary manner that serve no legitimate governmental purpose, for that would be inconsistent with the rule of law and the fundamental premises of the constitutional state. The purpose of this aspect of equality is, therefore, to ensure that the state is bound to function in a rational manner. This has been said to promote the need for governmental action to relate to a defensible vision of the public good ...

In light of the above and in order to deal with the complexities of enforcing the right to equality and determine whether or not an Act of Parliament violates that right, the Court developed a three-staged inquiry in Harksen $v$ Lane under the interim Constitution of the Republic of South Africa Act 200 of 1993, the provisions of which were replaced by the Constitution. The inquiry is described by the Court as involving the following questions: ${ }^{38}$

(a) Does the provision differentiate between people or categories of people? If so, does the differentiation bear a rational connection to a legitimate government purpose? If it does not then there is a violation of section 9(1). Even if it does bear a rational connection, it might nevertheless amount to discrimination.

(b) Does the differentiation amount to unfair discrimination? This requires a two stage analysis:

than record or confer formal equality', and reasoned that '[w]e care about equality - both formal and substantive - because we recognise the equal and inherent worth of all human beings'); City Council of Pretoria v Walker 1998 (2) SA 363 para 73 (where it was held that the equality clause in the Constitution clearly calls for formal equality and more); $A B$ \& Another $v$ Minister of Social Development [2016] ZACC 43 (where it was held that the right to equality provides a mechanism to achieve substantive equality which, unlike formal equality that presumes that all people are equal, tolerates difference).

35 Bato Star Fishing (Pty) Ltd v Minister of Environmental Affairs and Tourism 2004 (4) SA 490 (CC).

36 Bato Star Fishing (n 35) para 74.

37 Prinsloo $v$ Van der Linde 1997 (6) BCLR 759; 1997 (3) SA 1012 paras 24-25.

38 Harksen $v$ Lane 1998 (1) SA 300 (CC) para 50. 
(i) Firstly, does the differentiation amount to discrimination? If it is on a specified ground, then discrimination will have been established. If it is not on a specified ground, then whether or not there is discrimination will depend upon whether, objectively, the ground is based on attributes and characteristics which have the potential to impair the fundamental human dignity of persons as human beings or to affect them adversely in a comparably serious manner.

(ii) If the differentiation amounts to discrimination, does it amount to unfair discrimination? If it has been found to have been on a specified ground, then unfairness will be presumed. If on an unspecified ground, unfairness will have to be established by the complainant. The test of unfairness focuses primarily on the impact of the discrimination on the complainant and others in his or her situation.

If, at the end of this stage of the enquiry, the differentiation is found not to be unfair, then there will be no violation of section $9(2)$.

(c) If the discrimination is found to be unfair then a determination will have to be made as to whether the provision can be justified under the limitations clause.

The courts have consistently applied the above inquiry to determine numerous allegations of breaches of the right to equality, particularly those alleging violations of subsection (1) of that right. ${ }^{39}$

\subsection{Applying the Harksen inquiry to the Government Employees Pension Fund Law}

In Wiese $v$ Government Employees Pension Fund, which dealt with an issue similar to the one being examined here, the High Court considered whether the Government Employees Pension Fund Law was constitutionally invalid due to its failure to apply the clean break principle. The case arose after the Pension Funds Act and Divorce Act 90 of 1979 were concurrently amended in 2007 to grant divorcees of members of pension funds governed by the Pension Funds Act immediate access to their pension benefits on the date of divorce. Prior to these amendments, divorcees' pension benefits would accrue to them only upon certain exit events such as retirement or resignation by the main pension member. The problem was that the non-member spouse was prejudiced because the value of his or her benefit did not grow during the waiting period before the exit event by the main member. Yet, the main pension member would benefit from the growth in value of the benefit during this period. As the High Court explained, the effect of the 2007 reforms is that they

39 See South African Police Service v Solidarity obo Barnard 2014 (6) SA 123 (CC); (2014) 35 ILJ 2981 (CC) 51 (suggesting that the Harksen test applies to allegations of breaches of sec 9(1) of the Constitution and not sec 9(2)). See also Khosa \& Others v Minister of Social Development 2004 (6) SA 505 (CC); National Coalition for Gay and Lesbian Equality (n 34); Jooste $v$ Score Supermarket Trading (Pty) Ltd (Minister of Labour Intervening) 1999 (2) SA 1 (CC); Hoffmann v South African Airways 2001 (1) SA 1 (CC); National Union of Metal Workers of South Africa obo Members $v$ Element Six Production (Pty) Ltd [2017] ZALCJHB 35; Van Heerden (n 34). 
amended the date of accrual of the pension benefits for a nonmember spouse so that the non-member spouse's pension benefits accrue on the date of divorce. ${ }^{40}$ In other words, following the reforms the non-member spouse no longer has to wait until the main pension member exits the fund in order to gain access to his or her pension benefits. There is no doubt that these reforms brought forth advantages to non-member spouses of pension members in South Africa.

The problem is that the advantages from the 2007 amendments did not apply to the Government Employees Pension Fund Law. In applying the Harksen inquiry to this case, the High Court found that the differentiation in that case was between non-member spouses of members of pension funds regulated by the Pension Funds Act and non-member spouses of members of the GEPF. It also found that the differentiation arose out of Parliament's omission to apply the 'clean break' principle on divorce to non-member spouses of members of the GEPF. The government did not defend the rationality of the differentiation nor did the Court find any legitimate government reason for the differentiation. The Court held that the omission in the Government Employees Pension Fund Law to provide the application of the 'clean break' principle rendered it in conflict with section 9(1) of the Constitution. For separation of powers necessities, the Court rejected to read-in words into the Government Employees Pension Fund Law as a remedy in favour of a suspended declaration of invalidity to allow Parliament to remedy the defect. In his study of constraints on judicial review, Okpaluba has correctly noted that 'as an incident of separation of powers, courts often state that they are illequipped to grant orders that could have multiple social and economic consequences'. ${ }^{41}$ This appears to be what motivated the High Court from not granting the reading-in remedy.

By the time the case reached the Court for confirmation of the order of invalidity as required by the section 167(5) of the Constitution, Parliament had amended the Government Employees Pension Fund Law to address the defect. The Court found that the substantive cause of action by the plaintiff had been rendered moot by that legislative intervention, and that the resolution of the validity of the Government Employees Pension Fund Law would have no practical effect on the parties. Therefore, it held that it was not in the interests of justice to consider the matter.

40 Wiese 1 (n 11) para 8. See also S Mothupi 'Some practical effects of the Financial Services Laws General Amendment Act 2008 on amending section 37D(4) of the Pension Funds Act' (2010) 22 SA Mercantile Law Journal; C Marumoagae 'A nonmember spouse's entitlement to the member's pension interest' (2014) 17 Potchefstroom Electronic Law Journal 2488.

41 C Okpaluba 'Constraints on judicial review of executive conduct: The juridical link between the Marikana mineworkers' imbroglio and the Gauteng E-tolling saga' (2015) 2 Journal for South African Law 286287. 
A similar cause of action was lodged in Ngewu challenging the Post Office Act for its omission to provide for a 'clean break' principle in its provisions. Despite the fact that the parties settled the matter, the Court found that the differentiation between the payments of divorced spouses' interests regulated by the Pension Funds Act and the Government Employees Pension Fund Law versus the Post Office Act was irrational due to the omission of the 'clean break' principle in the Post Office Act. ${ }^{42}$ The Court reasoned that this differentiation did not meet the standard of equality before the law and equal protection and benefit of the law.

As in Wiese, the government did not defend the impugned law nor did it seek to justify it. The Court declared the relevant provisions of the Post Office Act invalid and suspended the order of invalidity for eight months to allow Parliament to cure the constitutional defect. The Court also held that in the event that the defect was not cured within the stipulated time frame, the order to read-in section 24A of the Government Employees Pension Fund Law into the Post Office Act would automatically come into effect. Section 24A of the Government Employees Pension Fund Law was the provision that was passed to cure the constitutional defect identified by the High Court in Wiese.

The jurisprudence in Wiese and Ngewu is relevant to the problem which has preoccupied the pages of this article. There is a clear differentiation between members of the GEPF and members of pension funds governed by the Pension Funds Act with respect to access to justice at the OPFA. The differentiation arises out of the failure by Parliament to make provision for a specialised pension tribunal for members of the GEPF. Given that the Pension Funds Act affords members of pension funds governed by it the advantage of access to justice at no cost, there is no rational reason why the same advantage should be withheld from their counterparts in the GEPF. Unlike their counterparts under the Pension Funds Act, members of the GEPF have to incur substantial legal costs in order to vindicate their rights under the Government Employees Pension Fund Law and its rules. Recently, the Durban High Court highlighted this problem. In explaining why the losing party should not be liable for legal costs of litigation, the High Court in Ntshangase $v$ Government Employees Pension Fund reasoned: 43

During the course of argument I enquired from counsel for the respondent as to whether any provision existed in the rules of the respondent for a cost-effective and expeditious dispute resolution mechanism, or for a referral of disputes to an entity like the ... Adjudicator ...The respondent ought to make a conscientious attempt to have disputes resolved efficiently and in a cost-effective manner for members or beneficiaries who may feel aggrieved at a decision. Counsel for the respondent was unable to refer me to any provision in the rules for such mechanism. Moreover, the complete

\footnotetext{
$42 \quad$ Ngewu (n 12) para 17.

43 Ntshangase v Government Employees Pension Fund Case 6166/16 11 August 2017 (unreported) para 22.
} 
failure of the respondent to engage with the applicant over the issue of the amount of the benefit to be paid following the death of the deceased is regrettable. In light of this, I am of the view that the applicant, although the losing party, should not be liable for costs.

Despite the above reasoning and conclusion, the judgment in Ntshangase highlights the difficulties faced by members and beneficiaries of the GEPF due to the absence of a dispute resolution provision in the Government Employees Pension Fund Law. It is clear from the Ntshangase judgment that at the very least members and beneficiaries of the GEPF, who opt to vindicate their rights in court, have to pay for their own legal costs of litigation. The high cost of legal services and its impact on the underprivileged in South Africa has been well articulated by many commentators, including recently by Chief Justice Mogoeng when he observed that '[I]itigation is prohibitively expensive and therefore not an easily exercisable constitutional option for an average citizen'. ${ }^{44}$

For this reason, the legislative history of the Pension Funds Act is unambiguous that the legislature conceived of a way to give the poor and marginalised access to justice through the OPFA, where members of the pension funds can get the same judicial services that are available in the courts of law at no cost. ${ }^{45}$ However, the current state of affairs, which prevents members of the GEPF from access to free judicial service at the OPFA, is indefensible and requires urgent legislative intervention. However, what type of legislative interventions or policy considerations are required to be considered?

\section{Constitutional considerations}

\subsection{Separation of powers}

There are a myriad constitutional and international law considerations and policy options that the executive and the legislature will have to consider in its efforts to cure the defect in the Government Employees Pension Law. For reasons of the separation of powers, these considerations and options cannot properly be determined through the institution of judicial review. In other words, this is not a situation where, when approached by a litigant, the judiciary can simply grant a reading-in remedy because there are a range of policy choices available to the elected branches of government. The courts have developed an approach to deal with problems associated with circumstances where there may be more than one rational way of

44 See Economic Freedom Fighters v Speaker of the National Assembly 2016 (3) SA 580 (CC) para 52.

45 See Hansard, Parliamentary Debates 12 March 1996 469-472. 
dealing with a particular social challenge. ${ }^{46}$ In this regard, the Court in Bel Porto School Governing Body ${ }^{47}$ reasoned as follows: ${ }^{48}$

The fact that there may be more than one rational way of dealing with a particular problem does not make the choice of one rather than the others an irrational decision. The making of such choices is within the domain of the executive. Courts cannot interfere with rational decisions of the executive that have been made lawfully, on the grounds that they consider that a different decision would have been preferable.

The High Court acknowledged and applied the above approach in Wiese when it rejected the plaintiff's argument urging a reading-in remedy. ${ }^{49}$ The High Court offered the following three reasons, namely, that (i) reading-in should not be preferred if it is likely to result in budgetary intrusion; ${ }^{50}$ (ii) since there were a range of constitutionally defensible choices, including different choices for GEPF versus other private pension funds governed by the Pension Funds Act, it was appropriate to allow the legislature to grapple with those choices rather than the courts usurping that power; ${ }^{51}$ (iii) a reading-in remedy could have far-reaching and unforeseen consequences, and courts should be wary of granting such remedy when a full legislative process of drafting and consultation could bring to light difficulties or unintended consequences unforeseen by a court. ${ }^{52}$ What is clear from the separation of powers jurisprudence of the Court is that while a reading-in remedy is permissible, courts are cautious in granting it. ${ }^{53}$ Hence, it is submitted that the elected branches of government need proactively to address the current

46 See Glenister $v$ President of the Republic of South Africa \& Others 2011 (3) SA 347 (CC) para 65; Bel Porto School Governing Body \& Others $v$ Premier of the Western Cape Province \& Another 2002 (3) SA 265; 2002 (9) BCLR 891 para 49.

47 Bel Porto School Governing Body (n 46).

48 Bel Porto School Governing Body (n 46) para 49.

49 Wiese 1 (n 11) paras 33-37.

50 Wiese 1 para 29, citing Van der Merwe v Road Accident Fund 2006 (4) SA 230 (CC).

51 Wiese 1 paras 33-37.

$52 \quad$ Wiese 1 para 38.

53 See Director of Public Prosecutions Transvaal v Minister for Justice and Constitutional Development 2009 (4) SA 222 (CC) para 183; National Coalition for Gay and Lesbian Equality v Minister of Home Affairs 2000 (2) SA 1 (CC) para 75 (where it was held that '[i]n deciding to read words into a statute, a court should also bear in mind that it will not be appropriate to read words in, unless in so doing a court can define with sufficient precision how the statute ought to be extended in order to comply with the Constitution. Moreover, when reading in (as when severing) a court should endeavour to be as faithful as possible to the legislative scheme within the constraints of the Constitution'); De Lange v Smuts NO 1998 (3) SA 785 (CC); Van der Merwe (n 50) para 73 (where the Court stated that '[r]eading words into a provision arises when it is necessary to add words in order to cure it of constitutional inconsistency ... The "cured" provision must be consistent with the Constitution and its basic values. The result of the curative process must interfere with the statute as little as possible. The remedial step should be capable of sufficient precision and should be as faithful as possible to the legislative scheme at hand. Lastly, the resort to the surgical remedies of severance and reading-in should not be preferred if they are likely to lead to an unsupportable budgetary intrusion'). 
constitutional defect in the Government Employees Pension Law in order to prevent possible court intervention.

\subsection{South Africa's dispute resolution framework: What the government should consider when amending the Government Employees Pension Law}

In this final part of the article I examine the constitutional framework on the adjudication of disputes that will have to be considered by the legislative and executive branches of government. The primary reason that compels this examination is that the Constitution is the supreme law and any law or conduct in conflict with it is invalid. ${ }^{54}$ It is well established that South African constitutional law entitles everyone to the right to a fair and public hearing by a court or another independent and impartial tribunal in the determination of his or her legal rights and obligations. This right finds expression in section 34 of the Constitution, which provides that '[e]veryone has the right to have any dispute that can be resolved by the application of law decided in a fair public hearing before a court or, where appropriate, another independent and impartial tribunal or forum'.

The above provision embodies the legal framework on dispute resolution in South Africa, of which the scope has been determined by the Court. In De Lange $v$ Smuts the Court dealt with the constitutionality of a presiding officer at an insolvency inquiry, who was empowered to commit a recalcitrant examinee to prison under section 66 of the Insolvency Act 24 of 1936. In resolving this dispute, the Court had to determine whether the presiding officer, for purposes of section 34, is either a court or another independent and impartial tribunal or forum. In the course of adjudication, the Court made some important judicial remarks regarding the scope of section 34. These remarks are important for the executive and legislature to consider in the context of devising a remedy for the defects in the Government Employees Pension Law.

54 See Ferreira $v$ Levin NO \& Others; Vryenhoek \& Others $v$ Powell NO \& Others 1996 (1) SA 984 (CC); 1996 (1) BCLR 1 para 27 where it was held that '[t]he Court's order does not invalidate the law; it merely declares it to be invalid ... In this sense laws are objectively valid or invalid depending on whether they are or are not inconsistent with the Constitution. The fact that a dispute concerning inconsistency may only be decided years afterwards, does not affect the objective nature of the invalidity. The issue of whether a law is invalid or not does not in theory therefore depend on whether, at the moment when the issue is being considered, a particular person's rights are threatened or infringed by the offending law or not'; Merafong City Local Municipality $v$ AngloGold Ashanti Limited 2017 (2) BCLR 182 (CC); 2017 (2) SA 211 (CC) (Jafta dissenting) paras 134-136 (stating that 'legislation that was passed after the Constitution came into operation became invalid from inception. This is because section 2 tells us that such legislation is invalid ... But the declaration of invalidity of law or conduct does not invalidate the law or conduct in question. The court order merely declares the law or conduct invalid. In contrast it is the Constitution itself which invalidates laws or conduct inconsistent with it'). 
The Court in De Lange ruled that any dispute that can be resolved by application of law has to comply with section 34, that is to say, the dispute must be resolved before a court or, where applicable, another independent and impartial tribunal. ${ }^{55}$ According to De Lange, when dealing with a section 34 problem, the crucial inquiry is whether a forum involved is either a court or another independent and impartial tribunal or forum. ${ }^{56}$ If the answer is in the affirmative, the next inquiry will be whether it is appropriate to have the issues in dispute decided by such court or tribunal. ${ }^{57}$ Given that questions of what constitutes an independent and impartial tribunal or forum had not been comprehensively determined in South Africa prior to De Lange, the Court relied heavily on Canadian case law on these questions to develop South African law.

In this context, the Court found that there were three essentials conditions that characterise a court or another independent and impartial tribunal or forum. These are (a) security of tenure, which embodies the requirement that the decision maker be removable only for just cause and be secure against interference by the executive branch of government; ${ }^{58}$ (b) a considerable degree of financial security free from arbitrary interference by the executive branch of government that could affect the independence of a tribunal or forum; and (c) institutional independence with respect to matters that relate directly to the exercise of the tribunal's judicial function, judicial control over the administrative decisions that bear directly and immediately on the exercise of the judicial function.

According to the Court's reasoning in De Lange, while there is a close link between independence and impartiality, these nonetheless are separate requirements. Independence relates to the traditional value of judicial independence both in relation to the state of mind of the decision maker, but also their status or relationship to others. ${ }^{59}$ On the other hand, the Court explained that impartiality speaks to a state of mind of the decision maker in connection with the issues and the parties in an individual case. ${ }^{60}$ Accordingly, since both independence and impartiality are fundamental to individual and public confidence in the administration of justice, it is important that any tribunal or forum should be perceived as independent as well as

55 De Lange (n 53) para 66. In an earlier case, Nel v Le Roux NO 1996 (4) BCLR 592; 1996 (3) SA 562) (CC) para 14, the Court left open the question of whether a functionary in an independent and impartial tribunal or forum referred to in sec 22 of the interim Constitution (the predecessor to sec 34) in all cases had to be a judicial officer, who ordinarily functions as such, in the judicial arm of government.

56 De Lange (n 53) para 42.

57 As above.

58 De Lange (n 53) paras 70-71. See also I Currie \& J de Waal The new constitutional and administrative law (2001) 299-301.

59 De Lange (n 53) para 71.

60 De Lange para 71, citing $R v$ Valente (1985) 24 DLR $\left(4^{\text {th }}\right) 161169-175$. 
impartial. ${ }^{61}$ Borrowing from the Canadian Supreme Court decision in $R \vee$ Valente, ${ }^{62}$ the Court in De Lange declared that the requirement of independence under section 34 means that the 'status of a tribunal must guarantee not only its freedom from interference by the executive and legislative branches of government but also by any other external force such as business or corporate interests or other pressure groups'.63

To put it differently, section 34 is designed not only to protect against interference from executive or legislative branches of government, but also the inherent dangers from private interests. This interpretation of the scope of section 34 is consistent with the general design of the Constitution, which applies to both state and private action. ${ }^{64}$ There are other standards and measures of accountability inherent in section 34, such as the public nature of court proceedings, judicial reason-giving in judgments, the deliberative nature of civil procedure, the judicial appointment process and the doctrine of stare decisis. ${ }^{65}$

Recently, in Financial Service Board ${ }^{66}$ the High Court applied the above principles to determine whether a tribunal set up under the Financial Services Board Act 1990 was in line with section 34 of the Constitution. In this case, a member of the Financial Service Board (FSB) was appointed to the Appeals Board which is established in terms of section 26A of the Financial Services Board Act. The primary purpose of the Appeals Board is to resolve any dispute brought by a person aggrieved by a decision made by the FSB. The provisions establishing the Appeals Board were challenged on the basis that they were inconsistent with the section 34 of the Constitution. The argument advanced to attack the validity of the Appeals Board was that the presence of a member of the FSB on the Appeals Board exhibited institutional bias and a lack of independence required by sections 34 and 33 of the Constitution. ${ }^{67}$

In dismissing the challenge, the High Court relied heavily on Canadian authorities. It reasoned that individual and structural independence were not ends in themselves, but were desirable for the faith in the impartiality of a tribunal which they promote. Conradie J noted that the overall objective of guaranteeing independence is to ensure a reasonable perception of impartiality at an institutional and

61 De Lange para 71.

62 Valente (n 60) 161.

63 Valente (n 60) para 72, citing $R v$ Genereux (1992) 88 DLR $\left(4^{\text {th }}\right) 110$.

64 See sec 8 of the Constitution.

65 See De Beer $v$ North-Central Local Council and South-Central Local Council 2002 (1) SA 429 (CC). See also M Mhango 'Transformation and the judiciary' in C Hoexter \& M Olivier (eds) The judiciary in South Africa (2014) 75.

66 Financial Service Board v Pepkor Pension Fund (2000) 4 BPLR 347 (C).

67 See Sidumo \& Another $v$ Rustenburg Platinum Mines Ltd \& Others 2008 (2) SA 24 (CC) paras $135 \& 142-153$ (suggesting that secs 34 and 33 of the Constitution are mutually exclusive). 
not subjective level. He further observed that the test to determine this type of bias is whether, having regard to the parties who appear before a decision maker, a fully-informed person would harbour a reasonable apprehension of bias in a substantial number of cases. Based on this reasoning, Conradie was satisfied that the Appeals Board was an independent tribunal as envisaged by section 34 of the Constitution. As a result, he ruled that section 26(1) of the Financial Service Act was constitutionally valid. The decision in Financial Service Board was welcomed by some commentators, who observed that '[a]s a matter of practical necessity considerable deviations from the standard of independence set for courts will have to be tolerated when it comes to tribunals'. ${ }^{68}$

Therefore, the constitutional position in South Africa in relation to the resolution of disputes is that any dispute that can be resolved by application of law requires its determination to comply with section 34; that such disputes must be resolved publicly before a court or a tribunal. ${ }^{69}$ The legislature and the executive have to apply their minds to these constitutional considerations in addressing the defects in the Government Employees Pension Law.

From the foregoing analysis it is clear that the executive and the legislature have several options. Among these are, first, that they could amend the legislation and grant GEPF members access to the OPFA notwithstanding the problems associated with that tribunal; second, that they could establish a stand-alone tribunal and provide complainants with the right to appeal to the High Court as is the case under section 30P of the Pension Funds Act. In the event that a standalone tribunal is preferred, there are further options available to the political branches of the state. These include that (i) in terms of the constitution of tribunal members, the political branches of the state, under the authority of Financial Service Board, have an option to appoint a member of the Board of Trustees of the GEPF to occupy a position on the tribunal: (ii) the political branches will have to grapple with the question whether complainants to the tribunal will enjoy the right to legal representation at the tribunal. In this context, a policy decision will have to be made having due regard to section 3(3) of the Promotion of Administrative Justice Act 2000, which grants an administrator the discretion to permit a person to obtain legal representation in serious or complex cases, and the judgment by the Supreme Court of Appeal in Hamata, ${ }^{70}$ which confirmed the right to

68 Currie \& de Waal (n 58) 300 fn144.

69 De Lange $v$ Smuts (n 53) para 66.

70 Hamata \& Another $v$ Chairperson, Peninsula Technikon Internal Disciplinary Committee \& Others [2002] ZASCA 44 (noting that the factors that ought to be considered in determining whether legal representation may be granted include 'the nature of the charges brought, the degree of factual or legal complexity attendant upon considering them, the potential seriousness of the consequences of an adverse finding, the availability of suitably qualified lawyers ... the fact that there is a legally trained "judicial officer" presenting the case against the [respondent], and any other factor relevant to the fairness or otherwise of 
legal representation in certain complex cases; $^{71}$ (iii) the policy makers will have to consider issues of security of tenure of tribunal members, which embodies the requirement that a decision maker be removable only for just cause and be secure against interference. ${ }^{72}$ This aspect could enhance public confidence in the tribunal and carries with it budgetary implications, which are matters that fall within the domain of the elected branches of government; ${ }^{73}$ (iv) the legislature and the executive will have to consider whether the tribunal would be conferred with the power to make decisions (over questions of fact and law $)^{74}$ that will be deemed a civil judgment by a court of law; ${ }^{75}$ (v) given the jurisdictional difficulties experienced by the Adjudicator, the legislature and executive may have to consider granting broad jurisdictional powers to the envisaged tribunal taking into account recent transformative jurisprudence. ${ }^{76}$ For instance, I submit that in order to fall within the jurisdiction of the tribunal, the focus must expressly be placed on the substance of a complaint and not the form of the complaint. Ordinary complainants should not be expected to

confining the [respondent] to the kind of representation for which the representation rule expressly provides, will have to be considered'). See also Minister of Public Works \& Others v Kyalami Ridge Environmental Association 2001 (3) SA 1151 (CC) para 1184E (where it was held that 'ultimately, procedural fairness depends in each case upon the balancing of various relevant factors, including the nature of the decision, the rights affected by it, the circumstances in which it is made, and the consequences resulting from it').

71 For a proposition that the Pension Funds Act does not prohibit legal representation at the complainant's own cost, see Henderson $v$ Eskom \& Another (1999) 12 BPLR 353 (PFA); Osbourne v MM Retirement Annuity Fund \& Others (2008) 3 BPLR 228 (PFA); San Giorgio v Cape Municipal Pension Fund (2007) 2 BPLR 255 (PFA).

72 De Lange $v$ Smuts (n 53) paras 70-71.

73 See International Trade Administration Commission v SCAW South Africa (Pty) Ltd 2012 (4) SA 618 (CC); National Treasury \& Others $v$ Opposition to Urban Tolling Alliance \& Others 2012 (6) SA 223 (CC).

74 Campbell and Fell $v$ United Kingdom (1984) 7 EHRR 165, 80 Eur Ct HR (Ser A) 1; Le Compte, Van Leuven and De Meyere v Belgium (1981) 4 EHRR 1 para 51; Bryan $v$ United Kingdom (1995) 21 EHRR 342, 44/1994/491/573 (HUDOC).

75 See also sec 30(1) of the Pension Funds Act which in relation to the Adjudicator provides that 'any determination of the Adjudicator shall be deemed to be a civil judgment of any court of law had the matter in question been heard by such court, and shall be so noted by the clerk or the registrar of the court, as the case may be'. See sec 143(1) of the Labour Relations Act 66 of 1995, which provides that the Commission for Conciliation, Mediation and Arbitration (CCMA), a dispute resolution body established in terms of that Act, of which the arbitration awards are 'final and binding and may be enforced as if it were an order of the Labour Court'; and sec 64(1) of the Competition Act 1998 which provides that 'any decision, judgment or order of the Competition Tribunal or Competition Appeal Court may be served, executed and enforceable as if it were an order of the High Court'. See Mantsho $v$ Managing Director of the Municipal Employee Pension Fund [2015] ZAGPPHC 408 (where it was held that rulings of the Adjudicator are enforceable).

76 See Mungal $v$ Old Mutual Life Assurance Co SA Ltd; Freeman v Old Mutual Life Assurance Co SA Ltd (2010) 1 BPLR 11 (SCA) para 8 (holding that law complainants should not be expected to frame their complaints with legal expertise); Hoffmann v Pension Funds Adjudicator (2011) ZAWCHC 446; (2012) 2 All SA 198 (WCC); and Central Retirement Annuity Fund $v$ Adjudicator of Pension Fund (2006) 4 All SA 251. 
frame their complaints with legal precision; (vi) the question of accessibility is another aspect that will have to occupy the minds of policy makers. As one commentator has correctly observed, this deals with whether hearings would be held in the English language only or include other official languages of South Africa. ${ }^{77}$

Related to this question is the issue of whether the proceedings would require personal attendance and the giving of direct evidence by complainants or whether hearings would be conducted by means of documentary evidence alone. ${ }^{78}$ The legislature and the executive will have to apply their minds to questions of enforcement of the tribunal rulings taking into account existing problems in other legislative frameworks. ${ }^{79}$ The problems around the enforceability of tribunal rulings has in recent years been the subject of debate and academic examination in South Africa. ${ }^{80}$ In order to devise an effective solution to the problems affecting the GEPF, the legislature and the executive will have to consider existing research and conduct new research on the subject. Aside from the above constitutional and policy considerations, the legislature and the executive will need to have regard to international law, ${ }^{81}$ a topic that is beyond the scope of this article.

\section{Conclusion}

In Barkhuizen $v$ Napier ${ }^{82}$ Justice Ngcobo explained the importance of the guarantee to seek the assistance of courts or tribunals in section 34 of the South African Constitution. He noted that '[a]n orderly and fair resolution of disputes is fundamental to the stability of an orderly society, and vital to a society that, like ours, is founded on the rule of $\operatorname{law}^{\prime} .{ }^{83}$

Section 34 gives expression to this foundational value by guaranteeing to everyone the right to seek the assistance of a court. He therefore noted that 'section 34 not only reflects the foundational

77 M Nyenti 'Reforming the South African social security adjudication system: Innovative experiences from South African non-social security jurisdictions' (2016) 19 Potchefstroom Electronic Law Journal 1 7-8.

78 As above.

79 Nyenti (n 77) 10-11.

80 C Marumoagae 'Recognition of the concept of contempt of "determination" of the Pension Fund Adjudicator's determination: A missed opportunity - With particular reference to Mantsho $v$ Managing Director of the Municipal Employee Pension Fund and Others (37226/14) [2015] ZAGPPHC 408 (26 June 2015)' (2017) 50 De Jure 175-185.

81 See S v Makwanyane 1995 (3) SA 391; Glenister v President of the Republic of South Africa 2011 (3) SA 347 (CC). See N Dyani 'An opportunity missed for male rape survivors in South Africa: Masiya $v$ Director of Public Prosecutions and Another' (2008) 52 Journal of African Law 284.

82 Barkhuizen v Napier 2007 (5) SA 323 (CC).

83 Barkhuizen v Napier ( $\mathrm{n}$ 82) para 31. 
values that underlie our constitutional order, it also constitutes public policy'. ${ }^{84}$

The article has argued that the omission of dispute resolution procedures from the Government Employees Pension Law is a violation of the equal protection and benefit of the law and the guarantees in section 34 of the Constitution. It has been maintained that there is a positive constitutional obligation on the part of the state 'to respect, protect, promote and fulfil the rights in the Bill of Rights' ${ }^{85}$ In the present context, the executive branch has the authority and obligation, in terms of sections $85(2)(b)$ and (d) of the Constitution, proactively to develop policy and prepare and initiate legislation to cure the current constitutional defect. ${ }^{86}$ At the same time, the legislature has the obligation to cure the current constitutional defect by passing legislation that seeks to amend the Government Employees Pension Law. I have suggested that the two elected branches of government have various options on how to cure this defect. I have provided some of the policy and constitutional considerations that would need to be considered by these branches of government.

Finally, since the right to equality and access to courts in the South African Constitution mirror similar procedures in articles 14 and 26 of the International Covenant on Civil and Political Rights ${ }^{87}$ (which was ratified by most African countries and hence forms part of their normative framework) and articles 3, 7 and 19 of the African Charter, the arguments advanced in the article are relevant to and applicable to many of these African countries.

84 Barkhuizen $v$ Napier para 33.

85 Carmichele $v$ Minister of Safety and Security 2001 (4) SA 938 (CC); 2001 (10) BCLR 995 (CC) (where it was held that in some circumstances there would also be a positive component which obliges the state and its organs to provide appropriate protection to everyone through laws and structures designed to afford such protection'); Rail Commuters Action Group v Transnet Ltd t/a Metrorail 2005 (2) SA 359 (CC) (where it was ruled that in some circumstances, the correlative obligations imposed by the rights in the Bill of Rights will require positive steps to be taken to fulfil the rights'); Glenister (n 46 above) paras 189-190 (where it was held that sec $7(2)$ of the Constitution, which provides 'the state to respect, protect, promote and fulfil the rights in the Bill of Rights', imposes a positive obligation on the state and its organs - to provide appropriate protection to everyone through laws and structures designed to afford such protection).

86 See Electronic Media Network Limited v ETV (Pty) Limited (2017) ZACC 17 paras 2-16 (where in rejecting the plaintiff's substantive challenge to the executive's policy choices on digital migration, the Court reasoned that 'one of the core features of [executive] authority is national policy development. For this reason, any legislation, principle or practice that regulates a consultative process or relates to the substance of national policy must recognise that policy-determination is the space exclusively occupied by the executive'). 